\title{
Retrospektywna analiza zakażeń u pacjentów po przeszczepieniu nerki*
}

\section{Retrospective analysis of infections in patients after kidney transplantation}

\author{
Joanna Czarnota-Chlewicka \\ Samodzielna Pracownia Opieki Długoterminowej Pomorskiego Uniwersytetu Medycznego w Szczecinie \\ ul. Dezyderego Chtapowskiego 11, 70-103 Szczecin \\ Kierownik: dr n. med. Maria Korzonek
}

\section{SUMMARY}

Introduction: Transplantation is the best way of treatment in end-stage renal disease. Kidney transplantation is the most common among all transplantations of vascularised organs. The development of transplantational immunology, as well as the improvement of schemes of immunosuppressive treatment decrease the number of episodes of acute rejection. They also allow perennial functioning of the transplanted organ. However, the necessity to dampen the immune system, through the delivery of immunosuppressive drugs (to prevent rejection), contributes to a deterioration in the ability of the body to fight infections. Patients after kidney transplantation are in the group at special risk of bacterial, viral and fungal infections, which poses an essential therapeutic problem.

The aims of this work were: the retrospective analysis of infections in patients after kidney transplantation, analysis of etiologic factors and the form of clinical infections, and the establishment of the risk factors of infections in the recipients of kidney transplant.
Material and methods: 147 patients hospitalized from 1.01.2007 to 31.12.2008 at the Department of Nephrology and Kidney Transplantation in the Independent Public Provincial Hospital in Szczecin were considered in the study. The data were obtained from medical records, i.e. operative reports on kidney transplant, patient's history, and the results of microbiological and serological examinations.

Conclusions: 1 . High risk of infection occurred in the case of: low compatibility in the human leukocyte antigen system, long cold ischemia time, and in recipients who required higher doses of corticosteroids. 2. Prompt diagnosis of the infection and the early implementation of suitable therapy seems to be fundamental for the effectiveness of treatment and the prevention of further infectious complications in patients after kidney transplantation.

Key words: postoperative infection, kidney transplantation, infectious complications.

\section{STRESZCZENIE}

Wstęp: Transplantacja nerki jest najlepszym sposobem leczenia schyłkowej niewydolności tego narządu i najczęściej wykonywanym zabiegiem spośród wszystkich transplantacji narządów unaczynionych. Rozwój immunologii transplantacyjnej oraz udoskonalanie schematów leczenia immunosupresyjnego powodują zmniejszenie liczby epizodów ostrego odrzucania i pozwalają na wieloletnie funkcjonowanie przeszczepionego organu. Jednak konieczność osłabiania systemu odpornościowego poprzez przyjmowanie leków immunosupresyjnych w celu zapobiegania odrzucania przeszczepu przyczynia się do pogorszenia możliwości organizmu w walce $\mathrm{z}$ infekcjami. Pacjenci po przeszczepieniu nerki są w grupie szczególnego ryzyka zakażeń bakteryjnych, wirusowych i grzybiczych, które stanowią istotny problem terapeutyczny.

Celem pracy była retrospektywna analiza zakażeń u pacjentów po przeszczepieniu nerki i ustalenie czynników etiologicznych oraz postaci klinicznych zakażeń, a także ustalenie czynników ryzyka zakażenia u biorców nerki.

Materiał i metody: Badaniami objęto 147 pacjentów hospitalizowanych na Oddziale Nefrologii i Transplantacji Nerek w Samodzielnym Publicznym Wojewódzkim Szpitalu Zespolonym w Szczecinie w okresie 1.01.2007-31.12.2008 r. Dane do badań zostały uzyskane z dokumentacji medycznej - protokołów przeszczepiania nerki, historii choroby oraz wyników badań mikrobiologicznych i serologicznych.

Wnioski: 1. Podwyższone ryzyko wystąpienia zakażenia występowało w przypadku niskiej zgodności w układzie zgodności tkankowej HLA, długiego czasu niedokrwienia oraz u biorców, u których była konieczność stosowania większych dawek glikokortykosteroidów. 2. Szybkie rozpoznanie zakażenia i wczesne wdrożenie odpowiedniej terapii wydaje się mieć fundamentalne znaczenie dla skuteczności leczenia oraz profilaktyki dalszych powikłań infekcyjnych u pacjentów po przeszczepie nerki.

Słowa kluczowe: zakażenie pooperacyjne, przeszczepienie nerki, powikłanie infekcyjne.

* Zwięzła wersja rozprawy doktorskiej przyjętej przez Radę Wydziału Nauk o Zdrowiu Pomorskiego Uniwersytetu Medycznego w Szczecinie. Promotor: prof. dr hab. n. med. Stefania Giedrys-Kalemba. Oryginał obejmuje: 84 strony, 22 tabele, 2 ryciny, 213 pozycji piśmiennictwa. 


\section{WSTĘP}

Transplantacja nerki jest najlepszym sposobem leczenia schyłkowej niewydolności tego narządu i najczęściej wykonywanym zabiegiem spośród wszystkich transplantacji narządów unaczynionych. Rozwój immunologii transplantacyjnej oraz udoskonalanie schematów leczenia immunosupresyjnego przyczyniają się do zmniejszenia liczby epizodów ostrego odrzucania i pozwalają na wieloletnie funkcjonowanie przeszczepionego organu. Jednak konieczność osłabiania systemu odpornościowego poprzez przyjmowanie leków immunosupresyjnych celem zapobiegania odrzucania przeszczepu powoduje pogorszenie możliwości organizmu w walce z infekcjami. Dlatego pacjenci po przeszczepieniu nerki są w grupie szczególnego ryzyka zakażeń bakteryjnych, wirusowych i grzybiczych, które stanowią istotny problem terapeutyczny.

Celem pracy była analiza zakażeń u pacjentów po przeszczepieniu nerki oraz czynników etiologicznych i postaci klinicznych zakażeń, a także próba ustalenia czynników ryzyka zakażenia u biorców nerki.

\section{MATERIA I METODY}

Badaniami objęto 147 pacjentów hospitalizowanych na Oddziale Nefrologii i Transplantacji Nerek w Samodzielnym Publicznym Wojewódzkim Szpitalu Zespolonym w Szczecinie w okresie 1.01.2007-31.12.2008 r. Dane do badań zostały uzyskane z dokumentacji medycznej - protokołów przeszczepiania nerki, historii choroby oraz wyników badań mikrobiologicznych i serologicznych. Materiał do badań bakteriologicznych pobierano z ran, krwi, moczu oraz usuwanych cewników dializacyjnych.

Analizy zakażeń u pacjentów po przeszczepieniu nerki dokonano w oparciu o parametr częstości, czyli ilościowe wystąpienie analizowanej zmiennej lub zjawiska w określonej populacji, np. liczba (odsetek) zakażeń w ogólnej liczbie chorych, rodzaj poszczególnych czynników etiologicznych zakażeń.

Zebrane informacje o pacjentach zakodowano w postaci bazy danych i dokonano obliczeń w programie Microsoft Office Excel 2007 oraz poddano analizie statystycznej z wykorzystaniem programu Statistica PL 9 [1]. Ocenę zależności poszczególnych kategorii zmiennych jakościowych przeprowadzono, stosując test niezależności $\chi^{2} \mathrm{z}$ poprawką Yatesa lub test dokładny Fishera. Dopuszczalne prawdopodobieństwo p błędu pierwszego rodzaju (poziom istotności testu) przyjęto na poziomie $\mathrm{p} \geq 0,05$.

\section{WYNIKI}

Wśród przebadanej grupy 147 pacjentów było 83 (56,5\%) mężczyzn i $64(43,5 \%)$ kobiety w wieku 17-72 lat. Najwięcej hospitalizowanych (36\%) było w przedziale wiekowym 51-60 lat. Objawy zakażenia stwierdzono u 70 pacjentów, co stanowiło 47,6\% badanych. Najczęściej (50\%) objawy zakażenia występowały w najstarszej grupie wiekowej (61-72 lat) - tabela 1.
TABELA 1. Liczebność pacjentów hospitalizowanych na Oddziale Nefrologii i Transplantacji Nerek, w tym pacjentów z zakażeniem ze względu na wiek

\begin{tabular}{|c|c|c|c|c|}
\hline \multirow{3}{*}{$\begin{array}{l}\text { Wiek } \\
\text { (lata) }\end{array}$} & \multicolumn{4}{|c|}{ Pacjenci $(n=147)$} \\
\hline & \multicolumn{2}{|c|}{ razem } & \multicolumn{2}{|c|}{ z objawami zakażenia } \\
\hline & $n$ & $\%$ & $Z$ & $\%$ \\
\hline $17-30$ & 22 & 15 & 10 & 45,5 \\
\hline $31-40$ & 21 & 14,3 & 10 & 47,6 \\
\hline $41-50$ & 29 & 19,7 & 14 & 48,3 \\
\hline $51-60$ & 53 & 36 & 25 & 47,2 \\
\hline $61-72$ & 22 & 15 & 11 & 50 \\
\hline Razem & 147 & 100 & 70 & 47,6 \\
\hline
\end{tabular}

Do rozpoznania zakażeń wykorzystano badania kliniczne, mikrobiologiczne i serologiczne. Badania mikrobiologiczne zostały wykonane u wszystkich osób w przypadku podejrzenia zakażenia układu moczowego (ZUM), miejsca operowanego (ZMO) oraz sepsy. Do zdiagnozowania infekcji układu oddechowego, drożdżycy jamy ustnej oraz półpaśca zastosowano tylko badanie kliniczne.

U pacjentów po przeszczepieniu nerki występowały różne formy i postaci kliniczne zakażeń. U 45 (64,3\%) chorych stwierdzono jedną postać kliniczną zakażenia i najczęściej było to ZUM, które wystąpiło u 35 osób. U 18 (25,7\%) pacjentów wystąpiły dwie postaci kliniczne zakażenia, najczęściej ZUM i sepsa (4 osoby) oraz ZUM i zakażenie wirusem cytomegalii (4 osoby). U 7 (10\%) chorych zaobserwowano trzy postaci kliniczne, w tym u 4 osób rozpoznano ZUM, sepsę oraz infekcję CMV.

Spośród wszystkich postaci klinicznych zakażeń w badanej populacji dominowało zakażenie układu moczowego, które rozpoznano łącznie u 57 chorych, tj. u 81,4\%. U 12 (17,1\%) osób stwierdzono sepsę, natomiast u 9 (12,9\%) - zakażenie miejsca operowanego. Zakażenie wirusem cytomegalii obserwowano wśród 11 pacjentów, co stanowi 15,7\%. W pojedynczych przypadkach rozpoznano zakażenie dróg oddechowych (6), drożdżycę jamy ustnej (4), infekcję VZV (2) i wirusem Polyoma BK (1). Schorzenia te wystąpiły jako jedyne postacie kliniczne zakażenia u pacjenta (CMV i VZV) lub łącznie z inną postacią (tab. 2).

Analizie poddano częstość występowania poszczególnych rodzajów zakażeń u obu płci. W porównaniu z grupą kobiet, u mężczyzn częściej występowały takie zakażenia jak: ZMO $(18,4 \%$ vs $6,2 \%)$ oraz sepsa ( $21,1 \%$ vs $12,5 \%)$. Zakażenie układu moczowego w obu grupach wystąpiło w zbliżonym odsetku (81,6\% vs 81,2\%), podobnie jak zakażenie CMV (15,8\% vs 15,6\%), natomiast zakażenie VZV i BKV wystąpiły tylko u mężczyzn. W grupie kobiet odnotowano częstsze występowanie drożdżycy jamy ustnej (9,4\% vs 2,6\%) oraz zakażenie dróg oddechowych $(9,4 \%$ vs $7,9 \%)$ - tabela 2 .

Na podstawie analizy czasu wystąpienia zakażenia od momentu transplantacji nerki wykazano, że wysoce statystycznie istotne częstsze występowanie zakażenia odnotowano w pierwszym miesiącu od przeszczepu $(\mathrm{p}<0,001)$, które rozpoznano u 60 osób, co stanowi 85,7\%. W okresie 2-6 miesięcy po transplantacji zakażenie rozpoznano u 8 (11,4\%) chorych, natomiast zakażenie późne (po upływie 6 miesięcy 
TABELA 2. Charakterystyka występowania poszczególnych postaci klinicznych zakażeń w zależności od płci

\begin{tabular}{|c|c|c|c|c|c|c|}
\hline \multirow{3}{*}{ Postać kliniczna zakażenia } & \multicolumn{6}{|c|}{ Pacjenci z objawami zakażenia } \\
\hline & \multicolumn{2}{|c|}{ razem } & \multicolumn{2}{|c|}{ mężczyźni } & \multicolumn{2}{|c|}{ Kobiety } \\
\hline & $\mathrm{n}=70$ & $\%$ & $\mathrm{n}=38$ & $\%$ & $n=32$ & $\%$ \\
\hline Zakażenie układu moczowego & 57 & 81,4 & 31 & 81,6 & 26 & 81,2 \\
\hline Zakażenie miejsca operowanego & 9 & 12,9 & 7 & 18,4 & 2 & 6,2 \\
\hline Sepsa & 12 & 17,1 & 8 & 21,1 & 4 & 12,5 \\
\hline Zakażenie dróg oddechowych & 6 & 8,6 & 3 & 7,9 & 3 & 9,4 \\
\hline CMV & 11 & 15,7 & 6 & 15,8 & 5 & 15,6 \\
\hline VZV & 2 & 2,9 & 2 & 5,3 & - & - \\
\hline BKV & 1 & 1,4 & 1 & 2,6 & - & - \\
\hline
\end{tabular}

TABELA 3. Struktura zakażeń u pacjentów na Oddziale Nefrologii i Transplantacji Nerek ze względu na czas wystąpienia od transplantacji

Pierwszy epizod zakażenia po przeszczepieniu

\begin{tabular}{cccc}
\hline \multirow{2}{*}{$\begin{array}{c}\text { czas } \\
\text { (miesiące) }\end{array}$} & \multicolumn{2}{c}{ liczebność pacjentów } & $\mathbf{p}$ \\
\cline { 2 - 3 } $0-1$ & $\mathbf{n = 7 0}$ & $\%$ & $\begin{array}{c}1 \text { vs } 2 \\
<0,001\end{array}$ \\
\hline $2-6$ & $60^{1}$ & 85,7 & $\begin{array}{c}1 \text { vs } 3 \\
<0,001\end{array}$ \\
\hline$>6$ & $8^{2}$ & 11,4 & $\begin{array}{c}2 \text { vs } 3 \\
>0,10\end{array}$ \\
\hline
\end{tabular}

1 - cukrzyca w wywiadzie; 2 - cukrzyca potransplantacyjna; 3 - chorzy bez cukrzycy

od przeszczepienia nerki) wystąpiło u 2 (2,9\%) pacjentów. Wczesne zakażenie po przeszczepie nerki odnotowano ponad 7-krotnie częściej niż zakażenie w późniejszych miesiącach (2-6 miesięcy) oraz aż 30-krotnie częściej niż zakażenie późne (>6 miesięcy) - tabela 3 .

Do badań mikrobiologicznych najczęściej pobierano mocz $(50,4 \%)$ i krew $(31,8 \%)$, następnie wymaz z miejsca operowanego $(9,5 \%)$ i płyn z okolicy przeszczepionej nerki $(6,8 \%)$. Niewielki odsetek stanowiły posiewy treści z jamy brzusznej $(0,8 \%)$ i końcówek cewników dializacyjnych $(0,4 \%)$. W pojedynczych przypadkach pobierano próbki plwociny (0,08\%), kału $(0,08 \%)$ oraz wymaz z cewki moczowej $(0,2 \%)$. Łącznie wykonano 1169 badań, średnio 7,9 na jednego pacjenta. Wyniki dodatnie stanowiły 12,7\% badań. Najczęściej uzyskano je z posiewów cewników dializacyjnych (20\%) oraz moczu $(16,5 \%)$, w dalszej kolejności z rany pooperacyjnej $(9,9 \%)$, krwi $(9,1 \%)$ oraz ze zbiornika okołonerkowego $(6,3 \%)$.

Na podstawie otrzymanych dodatnich wyników badań mikrobiologicznych wykryto 148 drobnoustrojów, które zostały uznane za prawdopodobny czynnik etiologiczny zakażenia (ten sam gatunek drobnoustroju izolowany od tego samego pacjenta, ale z innego materiału został wliczony do ogólnej liczby drobnoustrojów). Najczęściej były to pałeczki Gram-ujemne - 83,1\%, a rzadziej ziarenkowce Gram-dodatnie - 16,2\%. W jednym przypadku odnotowano zakażenie grzybicze $(0,7 \%)$.

W grupie ziarenkowców Gram-dodatnich najczęściej izolowano bakterie z rodzaju Enterococcus $(66,7 \%)$, następnie Staphylococcus (29,2\%), najrzadziej Streptococcus $(4,2 \%)$. Najczęściej izolowanymi gatunkami były: Enterococcus faecium (29,2\%), Enterococcus faecalis (25,0\%), Staphylococcus haemolyticus MRCNS (16,7\%) oraz Enterococcus faecalis HLAR(+) (12,5\%). W grupie pałeczek Gram-ujemnych najczęściej izolowano pałeczki z rodziny Enterobacteriacae (78,9\%), wśród których dominującym gatunkiem była Escherichia coli $(43,9 \%)$, a znacznie rzadziej pałeczki niefermentujące - 20,3\% i poniżej 1\% pałeczki beztlenowe z rodzaju Bacteroides. U 14 (20\%) biorców nerki rozpoznano również obecność zakażenia wirusowego. Najczęściej było to zakażenie wirusem cytomegalii, które wystąpiło u 11 chorych. Zakażenie VZV (półpasiec) zdiagnozowano u 2 pacjentów, a przewlekłą nefropatię BK u 1 osoby.

Analizie poddano również częstość występowania drobnoustrojów izolowanych w postaciach klinicznych zakażeń. Najczęściej izolowaną grupą drobnoustrojów, niezależnie od postaci klinicznej zakażenia, były pałeczki Gram-ujemne $(75,9 \%)$, w mniejszym odsetku ziarenkowce Gram-dodatnie $(14,8 \%)$. W zakażeniach układu moczowego dominowała Escherichia coli (41,2\%), w mniejszych odsetkach izolowano Pseudomonas aeruginosa $(11,3 \%)$ i Klebsiella oxytoca $(8,2 \%)$. Wśród czynników etiologicznych ZMO w podobnych odsetkach występowały zarówno pałeczki Gram-ujemne z rodzaju Escherichia coli (18,8\%), Klebsiella oxytoca (12,5\%), Pseudomonas aeruginosa (12,5\%), jak i ziarenkowce Gram-dodatnie z rodzaju Enterococcus faecium (18,8\%) oraz Enterococcus faecalis (12,5\%). W sepsach najczęściej izolowano pałeczki Gram-ujemne, wśród których dominowały Escherichia coli $(31,4 \%)$, Pseudomonas aeruginosa $(28,6 \%)$ i Klebsiella oxytoca $(11,4 \%)$, a także metycylinooporny szczep Staphylococcus haemolyticus $(11,4 \%)$. U większości pacjentów (10) pierwotnym miejscem zakażenia prowadzącym do sepsy był układ moczowy. U pozostałych 2 pacjentów rozpoznano w pierwszym przypadku sepsę odcewnikową wywołaną przez Staphylococcus haemolyticus MRCNS(+), natomiast w drugim przypadku bakteriemię pierwotną, której czynnik etiologiczny stanowiła izolowana z krwi Escherichia coli (tab. 4).

Najczęściej objawy zakażenia wystąpiły u biorców, u których zgodność w układzie tkankowym HLA ze zgodnością HLA dawcy wynosiła 7-10 pkt $(55,5 \%)$ oraz 0-6 pkt (50\%). Wśród grupy, u której zgodność tkankowa w układzie HLA była większa i wynosiła 16-24 pkt, zakażenie odnotowano u $37,9 \%$. Na podstawie testu na porównanie wszystkich 
TABELA 4. Częstość występowania drobnoustrojów w poszczególnych postaciach klinicznych zakażeń u pacjentów po przeszczepieniu nerki leczonych na Oddziale Nefrologii i Transplantacji Nerek

\begin{tabular}{|c|c|c|c|c|c|c|c|c|}
\hline \multirow{3}{*}{$\begin{array}{c}\text { Postać kliniczna } \\
\text { Liczba szczepów } \\
\text { Drobnoustrój }\end{array}$} & \multirow{2}{*}{\multicolumn{2}{|c|}{$\begin{array}{c}\text { ZUM } \\
97\end{array}$}} & \multirow{2}{*}{\multicolumn{2}{|c|}{$\begin{array}{c}\text { ZMO } \\
16\end{array}$}} & \multirow{2}{*}{\multicolumn{2}{|c|}{$\begin{array}{c}\text { Sepsa } \\
35\end{array}$}} & \multirow{2}{*}{\multicolumn{2}{|c|}{$\begin{array}{c}\text { Razem } \\
162\end{array}$}} \\
\hline & & & & & & & & \\
\hline & $n$ & $\%$ & $\mathrm{n}$ & $\%$ & $\mathrm{n}$ & $\%$ & $\mathrm{n}$ & $\%$ \\
\hline Pateczki Gram-ujemne & 83 & 85,6 & 9 & 56,3 & 31 & 88,6 & 123 & 75,9 \\
\hline Escherichia coli & 40 & 41,2 & 3 & 18,8 & 11 & 31,4 & 54 & 33,3 \\
\hline Escherichia coli ESBL(+) & 2 & 2,1 & - & - & 2 & 5,7 & 4 & 2,5 \\
\hline Klebsiella oxytoca ESBL(+) & 4 & 4,1 & - & - & 1 & 2,9 & 5 & 3,1 \\
\hline Citrobacter freundii & 3 & 3,1 & - & - & - & - & 3 & 1,9 \\
\hline Citrobacter freundii ESBL(+) & 2 & 2,1 & - & - & - & - & 2 & 1,2 \\
\hline Proteus mirabilis ESBL(+) & 2 & 2,1 & - & - & 2 & 5,7 & 4 & 2,5 \\
\hline Proteus vulgaris & 3 & 3,1 & 1 & 6,3 & - & - & 4 & 2,5 \\
\hline Providencia rettgeri & 1 & 1,0 & - & - & - & - & 1 & 0,6 \\
\hline Morganella morganii & 2 & 2,1 & - & - & - & - & 2 & 1,2 \\
\hline Morganella morganii ESBL(+) & 2 & 2,1 & - & - & - & - & 2 & 1,2 \\
\hline Pseudomonas aeruginosa & 11 & 11,3 & 2 & 12,5 & 10 & 28,6 & 23 & 14,2 \\
\hline Serratia marcescens & - & - & - & - & 1 & 2,9 & 1 & 0,6 \\
\hline Bacteroides melaninogenica & - & - & 1 & 6,3 & - & - & 1 & 0,6 \\
\hline Acinetobacter baumannii & 2 & 2,1 & - & - & - & - & 2 & 1,2 \\
\hline Ziarenkowce Gram-dodatnie & 13 & 13,4 & 7 & 43,8 & 4 & 11,4 & 24 & 14,8 \\
\hline Enterococcus faecium & 4 & 4,1 & 3 & 18,8 & - & - & 7 & 4,3 \\
\hline Enterococcus faecalis HLAR(+) & 3 & 3,1 & - & - & - & - & 3 & 1,9 \\
\hline Enterococcus faecalis & 4 & 4,1 & 2 & 12,5 & - & - & 6 & 3,7 \\
\hline Staphylococcus aureus & 1 & 1,0 & - & - & - & - & 1 & 0,6 \\
\hline Staphylococcus haemolyticus MRCNS(+) & - & - & - & - & 4 & 11,4 & 4 & 2,5 \\
\hline Staphylococcus lugdunensis & - & - & 1 & 6,3 & - & - & 1 & 0,6 \\
\hline Streptococcus beta-hemolytic group C & 1 & 1,0 & - & - & - & - & 1 & 0,6 \\
\hline Grzyby & & & & & & & 1 & 0,6 \\
\hline Candida albicans & 1 & 1,0 & - & - & - & - & 1 & 0,6 \\
\hline Wirusy & & & & & & & 14 & 8,6 \\
\hline CMV & - & - & - & - & - & - & 11 & 6,8 \\
\hline VZV & - & - & - & - & - & - & 2 & 1,2 \\
\hline BKV & - & - & - & - & - & - & 1 & 0,6 \\
\hline
\end{tabular}

możliwych struktur nie wykazano różnic istotnych statystycznie $(p=0,44)$.

Najmniej zakażeń (20\%) wystąpiło u chorych znajdujących się w grupie osób, którym wszczepiono narząd o najkrótszym czasie zimnego niedokrwienia, tj. do 5,5 godz., natomiast najwięcej $(60 \%)$ u chorych, u których czas zimnego niedokrwienia (CIT) narządu przygotowanego do wszczepienia wynosił 13-18,5 godz. W pozostałych grupach chorych w zależności od czasu niedokrwienia odsetek zakażeń wynosił 40-56,5\%. Różnice dla wszystkich możliwych porównań nie były statystycznie istotne $(p=0,57)$.

Wystąpienie zakażenia oceniono w grupie pacjentów z cukrzycą rozpoznaną w wywiadzie oraz w grupie osób z cukrzycą potransplantacyjną, która wystąpiła u chorego po zastosowaniu immunosupresji, w tym dodatkowej dawki glikokortykosteroidów. Objawy zakażenia występowały istotnie częściej $(\mathrm{p}<0,02)$ w grupie pacjentów z cukrzycą potransplantacyjną $(55,3 \%)$ w porównaniu z grupą osób z cukrzycą rozpoznaną w wywiadzie $(18,8 \%)$. Zaobserwowano również, że istotnie częściej $(\mathrm{p}<0,03)$ objawy zakażenia wystąpiły w grupie osób niechorujących na cukrzycę $(48,8 \%)$ niż w grupie pacjentów z cukrzycą rozpoznaną w wywiadzie (18,8\%). Odsetek zakażeń był również nieco wyższy w grupie osób z rozpoznaną cukrzycą potransplantacyjną (55,3\%) niż w grupie osób niechorujących na cukrzycę (48,8\%), jednak w tym przypadku różnic istotnych statystycznie nie wykazano $(\mathrm{p}>0,47)$ - tabela 5 .

Dokonano również analizy między średnią dawką glikokortykosteroidów stosowanych u pacjentów przez pierwsze 3 miesiące po przeszczepieniu a częstością występowania zakażeń. Z przeprowadzonej analizy wynika, że w grupie chorych, która otrzymywała dodatkowe dawki glikokortykosteroidów, 
TABELA 5. Liczebność i odsetek pacjentów z zakażeniem po przeszczepieniu nerki leczonych na Oddziale Nefrologii i Transplantacji Nerek w zależności od występowania cukrzycy

\begin{tabular}{lccccc}
\multicolumn{1}{c}{ Cukrzyca } & \multicolumn{2}{c}{$\begin{array}{c}\text { Liczba } \\
\text { pacjentów }\end{array}$} & \multicolumn{2}{c}{$\begin{array}{c}\text { Pacjenci } \\
\text { z objawami } \\
\text { zakażenia }\end{array}$} & p \\
\cline { 2 - 5 } & $\mathbf{n = 1 4 7}$ & $\mathbf{1 0 0 \%}$ & $\mathbf{z = 7 0}$ & $\mathbf{4 7 , 6 \%}$ \\
\hline $\begin{array}{l}\text { Cukrzyca } \\
\text { W wywiadzie }\end{array}$ & 16 & 10,9 & 3 & 18,8 & $\begin{array}{r}1 \text { vs } 2 \\
<0,02\end{array}$ \\
\hline $\begin{array}{l}\text { Cukrzyca } \\
\text { potransplantacyjnann }\end{array}$ & 47 & 32 & 26 & 55,3 & $\begin{array}{l}1 \text { vs 3 } \\
<0,03\end{array}$ \\
\hline $\begin{array}{l}\text { Chorzy bez } \\
\text { cukrzycy }\end{array}$ & 84 & 57,1 & 41 & 48,8 & $\begin{array}{l}2 \text { vs } 3 \\
>0,47\end{array}$ \\
\hline
\end{tabular}

odsetek zakażeń był wyższy $(63,6 \%)$ w porównaniu z grupą, w której stosowano standardowe dawki glikokortykosteroidów (44,8\%), jednak różnic statystycznie istotnych nie wykazano $(\mathrm{p}=0,10)$.

\section{DYSKUSJA}

Przeszczepianie nerek jest metodą leczenia, która daje chorym ze schyłkową niewydolnością nerek największą szansę na odbudowę zdrowia oraz na powrót do aktywnego życia. U osób po przeszczepieniu wyraźnie większa jest satysfakcja z życia, lepszy stan psychiczny i emocjonalny oraz zdolność powrotu do pracy w porównaniu z pacjentami dializowanymi [2]. Należy jednak pamiętać, że oprócz wielu korzyści płynących z przeszczepienia narządu mogą pojawiać się różne komplikacje związane z zabiegiem operacyjnym i wystąpieniem powikłań po operacji oraz z leczeniem immunosupresyjnym [2]. Jak wskazują dostępne dane, biorcy nerek wciąż należą do grupy wysokiego ryzyka wystąpienia zakażenia, które może być wywołane przez szeroką gamę czynników chorobotwórczych [3]. Uważa się, że u ok. 70\% wszystkich osób po przeszczepieniu nerki występuje przynajmniej 1 epizod zakażenia w przeciągu 3 lat od transplantacji [4, 5].

W badaniach własnych przeanalizowano 147 osób, u których dokonano transplantacji nerki w latach 2007-2008. Odsetek zakażeń w badanej grupie wyniósł 47,6\%, a średnia liczba epizodów na jednego biorcę wynosiła 1,9.

Najczęściej zakażenia rozwijają się w pierwszym miesiącu po przeszczepieniu i zazwyczaj są to zakażenia układu moczowego, infekcje bakteryjne miejsca operowanego oraz zakażenia układu oddechowego [6]. Przytoczone informacje źródłowe potwierdzają badania własne, w których wskaźnik zakażeń również w pierwszym miesiącu był najwyższy i wynosił $85,7 \%$.

Według wielu autorów za większość powikłań infekcyjnych po przeszczepieniu nerki odpowiedzialne są bakterie Gram-ujemne, następnie bakterie Gram-dodatnie oraz grzyby $[7,8,9,10]$. Potwierdzają to chociażby badania przeprowadzone przez zespół naukowców z Meksyku, które wskazują, że większość zakażeń u biorców nerek wywołują pałeczki Gram-ujemne (55,5\%) reprezentowane głównie przez Escherichia coli $(36,2 \%)$, następnie ziarenkowce Gram-dodatnie
(25,9\%), wśród których dominują Enterococcus spp. (13,8\%) oraz Staphylococcus aureus $(4,4 \%)$, a w mniejszym odsetku grzyby $(18,6 \%)[9]$.

Podobne wyniki uzyskano w badaniach własnych, w których wśród wszystkich patogenów izolowanych z materiałów klinicznych najczęściej występowały pałeczki Gram-ujemne $(83,1 \%)$, a w mniejszym odsetku ziarniaki Gram-dodatnie $(16,2 \%)$.

W grupie pałeczek Gram-ujemnych najczęściej zakażenia wywoływały pałeczki z rodziny Enterobacteriacae $(78,9 \%)$, wśród których dominującym gatunkiem była Escherichia coli (43,9\%), następnie Klebsiella oxytoca $(11,4 \%)$. Z grupy ziarenkowców Gram-dodatnich najczęściej izolowano bakterie z rodzaju Enterococcus (66,7\%), wśród których dominowały Enterococcus faecium (29,2\%) oraz Enterococcus faecalis (25,0\%), a także szczepy Enterococcus faecalis z wysokim poziomem oporności na aminoglikozydy, które stanowiły 12,5\%.

Zdecydowana większość autorów jest zgodna, że najczęstszą postacią zakażeń u biorców nerek jest zakażenie układu moczowego $[10,11,12,13]$. Potwierdzają to badania własne, w których odsetek ZUM był największy i wynosił 81,4\%. Odsetek ten jest nieco wyższy niż w innych krajach. Pelle i wsp. podają, że we Francji ZUM występował u 77\% osób [14], natomiast badania wykonane w Iranie u 41,5\% [15].

Escherichia coli uważana jest za główny czynnik etiologiczny zakażenia układu moczowego, co potwierdza w swoich publikacjach wielu autorów $[8,15,16,17,18,19]$. Sqalli i wsp. w przeprowadzonych badaniach w Maroku wykazali, że ZUM wystąpił u $42 \%$ pacjentów po przeszczepie nerki, z czego $60 \%$ wywołanych było przez Escherichia coli, a następnie przez Klebsiella oxytoca (30\%) [18]. Także w badaniach własnych najczęstszym czynnikiem etiologicznym odpowiedzialnym za infekcje dróg moczowych była Escherichia coli (41,2\%), następnie Pseudomonas aeruginosa $(11,3 \%)$ oraz Klebsiella oxytoca $(8,2 \%)$.

W analizowanym własnym materiale drugą postacią kliniczną najczęściej diagnozowaną była sepsa (17,1\%), następnie zakażenie wirusem cytomegalii (15,7\%), zakażenie miejsca operowanego (12,9\%), infekcja dróg oddechowych $(8,6 \%)$ oraz drożdżyca jamy ustnej (5,7\%).

Z przeprowadzonych badań przez zespół naukowców w Meksyku wynika, że spośród analizowanej grupy 161 pacjentów z zakażeniem sepsę zdiagnozowano w 36 przypadkach, w tym 20 przypadków bakteriemii pierwotnej, za powstanie których odpowiedzialne były w większości pałeczki Gram-ujemne (16), a następnie gronkowce koagulazoujemne (4). Wśród tej samej grupy rozpoznano również 16 przypadków wtórnej bakteriemii, z czego 9 stanowiły urosepsy, a 2 bakteriemie odcewnikowe [9].

W materiale własnym najczęściej izolowanym patogenem odpowiedzialnym za rozwój sepsy były pałeczki Gram-ujemne (88,6\%), wśród których dominowały Escherichia coli $(31,4 \%)$ oraz Pseudomonas aeruginosa $(28,6 \%)$. Wśród bakterii Gram-dodatnich najliczniejszą grupę stanowił oporny na metycylinę, koagulazoujemny Staphylococcus haemolyticus (MRCNS) - 11,4\%. U większości pacjentów pierwotnym miejscem zakażenia prowadzącym do sepsy był układ moczowy. 
Zakażenie miejsca operowanego u biorców nerek jest częstym powikłaniem pooperacyjnym przyczyniającym się do wzrostu zachorowalności, śmiertelności, pogorszenia jakości życia pacjentów, wydłużenia czasu hospitalizacji oraz zwiększenia kosztów leczenia [20, 21]. Doniesienia literaturowe dotyczące częstości zakażenia miejsca operowanego u pacjentów po przeszczepieniu nerki mieszczą się w zakresie 4-8\% [20, 21, $22,23]$. W materiale własnym badania wydzieliny z miejsca operowanego, trzeciego najczęściej ocenianego materiału klinicznego, stanowiły 9,9\% wszystkich wykonanych badań dodatnich. Kliniczne objawy ZMO rozpoznano w wyższym odsetku $-12,9 \%$.

Na podstawie analizy Røine i wsp. w Norwegii wykazali, że ZMO wystąpiło u 9 (4,5\%) biorców nerek, a czynnikiem etiologicznym odpowiedzialnym za rozwój infekcji w obrębie rany pooperacyjnej były: Enterobacteriaceae u 5 pacjentów, Staphylococcus aureus u 3 i Pseudomonas u 1 osoby [23]. Wśród czynników etiologicznych wywołujących zakażenie miejsca operowanego u pacjentów stanowiących materiał badań własnych, podobny udział miały zarówno pałeczki Gram-ujemne z rodzaju Escherichia coli (18,8\%) oraz Klebsiella oxytoca (12,5\%), jak i ziarenkowce Gram-dodatnie z gatunku Enterococcus faecium (18,8\%) oraz Enterococcus faecalis (12,5\%).

Zakażenia wirusowe stanowią istotny problem u biorców narządów unaczynionych i najczęściej dotyczą okresu 1.-6. miesiąca po transplantacji. Najczęściej występującą infekcją wirusową wśród biorców nerek jest zakażenie CMV, a ciężkość infekcji może wahać się od zakażenia bezobjawowego, poprzez zakażenia charakterystyczne dla poszczególnych narządów (ośrodkowy układ nerwowy, płuco, jelito, nerka przeszczepiona), aż do zakażenia rozsianego włącznie ze skutkiem śmiertelnym $[6,24,25]$. Na podstawie przeanalizowanej dokumentacji zakażenia wirusowe rozpoznano u 14 chorych, wśród których dominowało zakażenie wirusem cytomegalii. Jednocześnie była to trzecia najczęściej występująca postać kliniczna zakażenia stanowiąca 15,7\%. Zakażenie CMV najczęściej (72,7\% przypadków) obserwowano w okresie 2-6 miesięcy po transplantacji, pozostałe przypadki rozpoznano już w pierwszym miesiącu po przeszczepieniu. Podobne wyniki przedstawili Veroux $i$ wsp. z Włoch, którzy podają częstość występowania infekcji CMV wśród biorców nerek na poziomie ok. 16\% [19].

W badanej grupie chorych zakażenie wirusowe stwierdzono jeszcze u 3 osób: u 2 (2,9\%) pacjentów rozpoznano półpasiec (VZV), u 1 (1,4\%) osoby przewlekłą nefropatię BKV. Dane źródłowe wskazują na wyższy odsetek zakażeń tego typu wirusami $[6,26,27]$. Według analizy Sousa i wsp. odsetek zakażeń VZV u biorców nerek wynosił 9,1\% [26]. Natomiast z wieloletniej analizy przeprowadzonej przez Arness $i$ wsp. wynika, że ryzyko rozwoju zakażenia VZV wzrasta w kolejnych latach po przeszczepieniu; częstość występowania półpaśca u biorców nerki określają na 1,9\%, 5,6\%, 8,0\% i 11,2\% odpowiednio w 1., 2., 3. i 4. roku obserwacji [27].

Zakażenia grzybicze, biorąc pod uwagę wszystkich pacjentów poddanych transplantacji narządów i immunosupresji, najrzadziej występują u biorców nerek. W dalszym ciągu pozostają jednak istotną przyczyną chorobowości i śmiertelności w tej grupie chorych [6, 28]. W obserwowanej grupie pacjentów częstość występowania zakażeń grzybiczych była niewielka i dotyczyła zakażeń grzybami drożdżopodobnymi. U 4 osób rozpoznano na podstawie objawów klinicznych drożdżycę jamy ustnej, natomiast w 1 przypadku izolowano Candida albicans z próbki moczu. Drożdżyca jamy ustnej dotyczy ok. 20\% osób po transplantacji nerki i często występuje w pierwszych miesiącach po transplantacji [29].

Ryzyko wystąpienia zakażenia u biorców przeszczepu zależy od wzajemnego oddziaływania różnych czynników: rodzaju leczenia immunosupresyjnego, stanu klinicznego pacjenta, stanu jego odporności, ekspozycji epidemiologicznych w środowisku szpitalnym i pozaszpitalnym oraz profilaktyki przeciwbakteryjnej $[8,19,30]$.

W materiale własnym analizie poddano następujące czynniki ryzyka wystąpienia zakażenia: wiek, przyczyna niewydolności nerek, cukrzyca w wywiadzie i - jako powikłanie potransplantacyjne - zgodność w układzie HLA, czas zimnego niedokrwienia, poziom preformowanych przeciwciał limfocytotoksycznych (PRA) oraz rodzaj i wielkość stosowanej immunosupresji.

Analiza wieku, jako czynnika ryzyka wystąpienia zakażenia, nie wykazała różnic istotnych statystycznie. Większą tendencję występowania zakażeń (pomimo różnic nieistotnych statystycznie) wykazano w przypadku małej zgodności w układzie tkankowym HLA oraz dłuższego CIT pobranej nerki. Najczęściej objawy zakażenia wystąpiły u biorców, u których zgodność w zakresie HLA z dawcą mieściła się w przedziale punktowym 7-10 (55,5\%), natomiast przy największej zgodności (16-24 pkt) zakażenie wystąpiło u 37,9\% osób. Podobnie wyższą częstość wystąpienia zakażenia odnotowano w przypadku dłuższego niż 5,5 godz. czasu zimnego niedokrwienia. Najwyższy odsetek zakażeń, tj. 60\% wystąpił u biorców, gdy czas zimnego niedokrwienia wynosił 13-18,5 godz., zaś najniższy (20\%), gdy CIT był krótszy niż 5,5 godz.

Sousa i wsp. w swojej analizie wykazali, że każdy 30-minutowy przyrost czasu zimnego niedokrwienia pobranego narządu od zmarłego dawcy stanowi znaczny i niezależny związek z ryzykiem wystąpienia zakażenia [26]. Biorcy przeszczepów od dawców zmarłych, ale dobrze dobrani pod względem zgodności w zakresie antygenów HLA, oraz biorcy przeszczepów rodzinnych, szczególnie przy zgodności w zakresie dwóch haplotypów, mogą wymagać mniejszych dawek leków immunosupresyjnych, co pośrednio może mieć wpływ na mniejsze ryzyko wystąpienia infekcji [31].

Kolejnym analizowanym czynnikiem ryzyka wystąpienia zakażenia była cukrzyca. Jest ona jedną z częstszych przyczyn prowadzących do schyłkowej niewydolności nerek i w efekcie do transplantacji nerki [32]. Natomiast cukrzyca potransplantacyjna została opisana po raz pierwszy przez Thomasa Starzla w 1964 r. [33]. Obserwowano ją wówczas u 40-60\% chorych po przeszczepieniu nerki i było to spowodowane głównie stosowaniem dużych dawek glikokortykosteroidów. Glikokortykosteroidy oraz inhibitory kalcyneuryny, przy czym takrolimus bardziej niż cyklosporyna, są toksyczne dla wysp 
trzustkowych, przez co przyczyniają się do rozwoju zaburzeń gospodarki węglowodanowej [33, 34]. Cukrzyca stanowi istotny czynnik ryzyka zakażeń bakteryjnych i grzybiczych po przeszczepieniu nerki [9, 21,34]. Według doniesień Sumrani i wsp. infekcje były głównym powikłaniem u biorców nerek z cukrzycą i występowały u nich znacznie częściej niż w grupie kontrolnej (53\% vs 16\%, p < 0,05) [35].

W badanej grupie nefropatia cukrzycowa była przyczyną niewydolności nerek u 14 chorych, co stanowi 9,5\% wszystkich przypadków. Objawy zakażenia w tej grupie stwierdzono u 21,4\% osób. Istotnie częściej objawy zakażenia występowały w grupie pacjentów z cukrzycą potransplantacyjną (55,3\%) w porównaniu z grupą osób z cukrzycą rozpoznaną w wywiadzie (18,8\%). Również istotnie częściej objawy zakażenia wystąpiły w grupie osób nie chorujących na cukrzycę niż w grupie pacjentów, którzy na nią chorują.

Powikłania infekcyjne są nieuniknionym skutkiem leczenia immunosupresyjnego i wynikają z ogólnej dawki stosowanej immunosupresji [32, 33]. Przynajmniej 1 epizod zakażenia $\mathrm{w}$ pierwszym roku po przeszczepieniu nerki odnotowuje się u 50-80\% wszystkich pacjentów, u których stosowany jest standardowy schemat leczenia immunosupresyjnego [4, 5, 8, 19, 26]. W badaniach własnych dokonano analizy między średnią dawką glikokortykosteroidów stosowanych u pacjentów przez pierwsze 3 miesiące po przeszczepie a częstością występowania zakażeń u tych chorych. Wykazano wyższy, aczkolwiek nieznamienny statystycznie, odsetek zakażeń w grupie chorych, która otrzymywała dodatkowe dawki glikokortykosteroidów w porównaniu z grupą chorych, u których stosowano standardowe dawki kortykosteroidów: $63,6 \%$ vs $44,8 \%$.

Inhibitory kalcyneuryny, pomimo swojego potencjału immunosupresyjnego, nie wpływają znacząco na wzrost częstości zakażeń oraz procesów nowotworowych [31]. Gaber i wsp. porównali dwie grupy pacjentów po przeszczepie nerki, u których stosowano odmienne protokoły immunosupresji. Pierwsza grupa otrzymywała sirolimus i takrolimus, a druga grupa - sirolimus i cyklosporynę. Wykazano podobny odsetek zakażeń w obu grupach, za wyjątkiem częstszego występowania zakażenia HSV w grupie osób otrzymujących takrolimus [36]. W materiale własnym w protokole leczenia immunosupresyjnego pacjenci po przeszczepieniu nerki 3-krotnie częściej otrzymywali takrolimus niż cyklosporynę, nie mniej odsetek zakażeń w obu grupach był również podobny $(47,3 \%$ vs $48,6 \%)$.

Transplantacja nerki jest metodą z wyboru leczenia przewlekłej niewydolności nerek w ich schyłkowym stadium. Jednakże ze względu na występującą zwykle większego lub mniejszego stopnia niezgodność tkankową, pacjenci po przeszczepie nerki muszą do końca życia przyjmować leki immunosupresyjne, co z jednej strony jest niezwykle istotne w prewencji odrzucania narządu, z drugiej zaś prowadzi do osłabienia ich układu odpornościowego i wzrostu podatności na różnego rodzaju infekcje. Dlatego niezmiernie ważne jest prowadzenie u biorców nerek systematycznej profilaktyki zakażeń uwzględniającej minimalizowanie czynników ryzyka, szybkiej ich diagnostyki i skutecznej terapii.

\section{WNIOSKI}

1. Na podstawie retrospektywnej analizy zakażeń u pacjentów po przeszczepieniu nerki wykazano, że:

a) do zakażenia doszło u prawie połowy pacjentów, u niektórych kilkakrotnie,

b) pierwszy epizod zakażenia najczęściej wystąpił w okresie pierwszego miesiąca po przeszczepieniu nerki,

c) najczęstszą postacią kliniczną było zakażenie układu moczowego,

d) wśród bakteryjnych czynników etiologicznych zakażeń dominowały pałeczki Gram-ujemne, najczęściej szczepy z rodziny Enterobacteriacae - Escherichia coli oraz Klebsiella oxytoca, wśród wirusowych - CMV.

2. Analizowane parametry: wiek, przyczyna niewydolności nerek, zgodność w układzie HLA, czas zimnego niedokrwienia, poziom PRA oraz rodzaj i wielkość stosowanej immunosupresji nie okazały się istotnym czynnikiem ryzyka wystąpienia zakażenia, aczkolwiek zakażenia obserwowano rzadziej w przypadku wysokiej zgodności w układzie HLA (16-24 pkt), krótkiego czasu niedokrwienia ( $<5,5$ godz.) oraz u biorców, u których stosowano standardową dawkę glikokortykosteroidów.

3. Szybkie rozpoznanie zakażenia i wczesne wdrożenie odpowiedniej terapii wydaje się mieć fundamentalne znaczenie dla skuteczności leczenia oraz profilaktyki dalszych powikłań infekcyjnych u pacjentów po przeszczepie nerki.

\section{PIŚMIENNICTWO}

1. Stanisz A.: Przystępny kurs statystyki z zastosowaniem Statistica Pl na przykładach z medycyny. Tom 1. Statystyki podstawowe. StatSoft, Kraków 2006.

2. Siddqi N., Hariharan S., Danovitch G.M.: Kwalifikacja i przygotowanie kandydatów do przeszczepienia nerki. In: Podręcznik transplantacji nerek. Ed. G.M. Danovitch. Wyd. Czelej, Lublin 2007, 115-130.

3. Fishman J.: Infection in renal transplant recipients. Semin Nephrol. 2007, 27 (4), 445-461.

4. Dharnidharka V.R., Agodoa L.Y., Abbott, K.C.: Risk Factors for hospitalization for bacterial or viral infection in renal transplant recipients - an analysis of USRDS data. Am J Transplant. 2007, 7 (3), 653-661.

5. Jha V.: Post-transplant infections: An ounce of prevention. Indian J Nephrol. 2010, 20 (4), 171-178.

6. Kubak B., Maree C., Pegues D., Hwang A.: Zakażenia w transplantacji nerek. In: Podręcznik transplantacji nerek. Ed. G.M. Danovitch. Wyd. Czelej, Lublin 2007, 191-225.

7. Durlik M., Meszaros J:: Zakażenia po przeszczepieniu narządu lub szpiku. In: Transplantologia kliniczna. Eds: W. Rowiński, J. Wałaszewski, L. Pączek. Wyd. Lek. PZWL, Warszawa 2004, 233-264.

8. Mahara B., Bonten H., Van Hooff H., Fiolet H., Buiting A.G., Stobberingh E.E.: Infectious complications and antibiotic use in renal transplant recipients during a 1-year follow up. Clin Microbiol Infect. 2001, 7 (11), 619-625.

9. Valdez-Ortiz R., Sifuentes-Osornio J., Morales-Buenrostro L.E., Ayala-Palma H., Dehesa-López E., Alberú J. et al.: Risk factors for infections requiring hospitalization in renal transplant recipients: a cohort study. Int J Infect Dis. 2011, 15 (3), e188-196.

10. Valera B., Gentil M.A., Cabello V., Fijo J., Cordero E., Cisneros J.M.: Epidemiology of urinary infections in renal transplant recipients. Transplant Proc. 2006, 38 (8), 2414-2415.

11. Alangaden G.: Urinary tract infections in renal transplant recipients. Curr Infect Dis Rep. 2007, 9 (6), 475-479.

12. de Souza R.M., Olsburgh J.: Urinary tract infection in the renal transplant patient. Nat Clin Pract Nephrol. 2008, 4 (5), 252-264. 
13. Senger S.S., Arslan H., Azap O.K., Timurkaynak F., Cağir U., Haberal M.: Urinary tract infections in renal transplant recipients. Transplant Proc. 2007, 39 (4), 1016-1017.

14. Pelle G., Vimont S., Levy P.P., Hertig A., Ouali N., Chassin C. et al.: Acute pyelonephritis represents a risk factor impairing long-term kidney graft function. Am J Transplant. 2007, 7 (4), 899-907.

15. Pourmand G., Salem S., Mehrsai A., Taherimahmoudi M., Ebrahimi R., Pourmand M.R.: Infectious complications after kidney transplantation: a single-center experience. Transpl Infect Dis. 2007, 9 (4), 302-309.

16. Chuang P., Parikh C.R., Langone A.: Urinary tract infections after renal transplantation: a retrospective review at two US transplant centers. Clin Transplant. 2005, 19 (2), 230-235.

17. Mitra S., Alangaden G.J.: Recurrent urinary tract infections in kidney transplant recipients. Curr Infect Dis Rep. 2011, 13 (6), 579-587.

18. Sqalli T.H., Laboudi A., Arrayhani M., Benamar L., Amar Y., Ouzeddoun N.: Urinary tract infections in renal allograft recipients from living related donors. Saudi J Kidney Dis Transpl. 2008, 19 (4), 551-553.

19. Veroux M., Giuffrida G., Corona D., Gagliano M., Scriffignano V., Vizcarra D. et al:: Infective complications in renal allograft recipients: epidemiology and outcome. Transplant Proc. 2008, 40 (6), 1873-1876.

20. Ho D., Lynch R.J., Ranney D.N., Magar A., Kubus J., Englesbe M.J.: Financial impact of surgical site infection after kidney transplantation: implications for quality improvement initiative design. J Am Coll Surg. 2010, 211 (1), 99-104.

21. Menezes F.G., Wey S.B., Peres C.A., Medina-Pestana J.O., Camargo L.F.: Risk factors for surgical site infection in kidney transplant recipients. Infect Control Hosp Epidemiol. 2008, 29 (8), 771-773.

22. Humar A., Ramcharan T., Denny R., Gillingham K.J., Payne W.D., Matas A.J.: Are wound complications after a kidney transplant more common with modern immunosuppression? Transplantation. 2001, 72 (12), 1920-1923.

23. Røine E., Bjørk I.T., Oyen O.E.: Targeting risk factors for impaired wound healing and wound complications after kidney transplantation. Transplant Proc. 2010, 42 (7), 2542-2546.

24. Durlik M., Meszaros J.: Zakażenia w transplantologii. In: Zakażenia szpitalne na oddziałach zabiegowych. Ed. M. Bulanda. Polskie Towarzystwo Zakażeń Szpitalnych, Kraków 2008, 257-280.
25. Humar A., Kumar D., Boivin G., Caliendo A.M.: Cytomegalovirus (CMV) virus load kinetics to predict recurrent disease in solid-organ transplant patients with CMV disease. J Infect Dis. 2002, 186 (6), 829-833.

26. Sousa S.R., Galante N.Z., Barbosa D.A., Pestana J.O.: Incidence of infectious complications and their risk factors in the first year after renal transplantation. J Bras Nefrol. 2010, 32 (1), 75-82.

27. Arness T., Pedersen R., Dierkhising R., Kremers W., Patel R.: Varicella zoster virus-associated disease in adult kidney transplant recipients: incidence and risk-factor analysis. Transpl Infect Dis. 2008, 10 (4), 260-268.

28. Alangaden G.J., Thyagarajan R., Gruber S.A., Morawski K., GarnickJ., El-Amm J.M. et al: Infectious complications after kidney transplantation: current epidemiology and associated risk factors. Clin Transplant. 2006, 20 (4), 401-409.

29. de la Rosa-Garcia E., Mondragon-Padilla A., Irigoyen-Camacho M.E., Bustamante Ramírez M.A.: Oral lesions in a group of kidney transplant patients. Med Oral Patol Oral Cir Bucal. 2005, 10 (3), 196-204.

30. Splendiani G., Cipriani S., Tisone G., Iorio B., Condo S., Vega A. et al.: Infectious complications in renal transplant recipients. Transplant Proc. 2005, 37 (6), 2497-2499.

31. Danovitch G.M.: Leki i protokoły immunosupresyjne w przeszczepianiu nerek. In: Podręcznik transplantacji nerek. Ed. G.M. Danovitch. Wyd. Czelej, Lublin 2007, 49-92.

32. Sahadevan M., Kasiske B.L.: Długotrwała opieka potransplantacyjna i powikłania. In: Podręcznik transplantacji nerek. Ed. G.M. Danovitch. Wyd. Czelej, Lublin 2007, 159-189.

33. Kaszuba-Wojtachnio E., Franek E., Duplik M., Rydzewski A.: Cukrzyca u chorych po przeszczepieniu narządów. Prz Gastroenterol. 2006, 1 (4), 179-183.

34. Gomes M.B., Cobas R.A.: Post-transplant diabetes mellitus. Diabetol Metab Syndr. 2009, 1 (1), 14

35. Sumrani N.B., Delaney V., Ding Z.K., Davis R., Daskalakis P., Friedman E.A. et al.: Diabetes mellitus after renal transplantation in the cyclosporine era - an analysis of risk factors. Transplantation. 1991, 51 (2), 343-347.

36. Gaber A.O., Kahan B.D., Van Buren C., Schulman S.L., Scarola J., Neylan J.F.: Comparison of sirolimus plus tacrolimus versus sirolimus plus cyclosporine in high-risk renal allograft recipients: results from an open-label, randomized trial. Transplantation. 2008, 86 (9), 1187-1195. 